\title{
Germanium incorporation into sponge spicules: Development of a proxy for reconstructing inorganic germanium and silicon concentrations in seawater
}

\author{
Michael J. Ellwood ${ }^{\mathrm{a}, *}$, Michelle Kelly ${ }^{\mathrm{b}}$, William A. Maher ${ }^{\mathrm{c}}$, Patrick De Deckker ${ }^{\mathrm{d}}$ \\ ${ }^{a}$ NIWA (National Institute of Water and Atmospheric Research), Gate 10, Silverdale Road, PO Box 11 115, Hamilton, New Zealand \\ ${ }^{\mathrm{b}}$ National Centre for Aquatic Biodiversity and Biosecurity, NIWA, Private Bag 109695, Auckland, 269 Khyber Pass Road, Newmarket, \\ Auckland, New Zealand \\ ${ }^{\mathrm{c}}$ EcoChemistry Laboratory, Division of Health, Design and Science, University of Canberra, Bruce ACT 2616, Australia \\ ${ }^{\mathrm{d}}$ Department of Earth and Marine Sciences, The Australian National University, Canberra, ACT 0200, Australia
}

Received 23 August 2005; received in revised form 9 December 2005; accepted 6 January 2006

Available online 17 February 2006

Editor: H. Elderfield

\begin{abstract}
Measurements of germanium (Ge) in deep-sea sponge skeletons are presented for sponges collected by dredge and for spicules isolated from a range of deep-sea sediment cores. Germanium to silicon $(\mathrm{Si})$ ratios $(\mathrm{Ge} / \mathrm{Si}$ sp $)$ for sponge silica ranged between 0.075 and $0.380 \mu \mathrm{mol} / \mathrm{mol}$, which are much lower than the present-day seawater $\mathrm{Ge} / \mathrm{Si}$ ratio of $0.7 \mu \mathrm{mol} / \mathrm{mol}$. A plot of Ge/ $\mathrm{Si}$ sp versus estimated seawater $\mathrm{Ge}$ (and $\mathrm{Si}$ ) concentration produced a linear relationship with the Ge content of spicules increasing with seawater $\mathrm{Ge}$ concentration. Plots of $\mathrm{Ge} / \mathrm{Si}_{\mathrm{sp}}$ versus depth for both dredged sponges and sediment-bound spicules produced oceanic profiles similar to those of dissolved $\mathrm{Ge}$ (and $\mathrm{Si}$ ) concentration. To explain the fractionation seen in the sponge $\mathrm{Ge} / \mathrm{Si}$ sp data two models are presented. The first model used to interpret the data assumes that sponges only respond to the Ge content of the ambient seawater, implying that, Ge incorporation into sponge silica is independent of the seawater $\mathrm{Ge} / \mathrm{Si}$ ratio up to a $\mathrm{Si}$ concentration of about $100 \mu \mathrm{mol} / \mathrm{L}$. This model is consistent with the ${ }^{68} \mathrm{Ge}$ uptake results of Davie et al. [E.I. Davie, T.L. Simpson, R. Garonne, Experimental germanium incorporation into siliceous sponge spicules, Biol. Cell 48 (1983) 191-202] for cultured spicules. Their results showed that the incorporation of Ge in sponge silica is only dependent on the Ge concentration of the water in which a sponge is growing. The second model used to explain the data assumes that $\mathrm{Ge} / \mathrm{Si}_{\mathrm{sp}}$ fractionation results from subtle differences in the uptake kinetics of Ge and Si. While the assumptions used by each model to describe the data are different, it is possible to use sponge $\mathrm{Ge} / \mathrm{Si}_{\mathrm{sp}}$ data to reconstruct palaeo-Ge concentrations using model I, and to reconstruct palaeo-Si concentrations using both models. Palaeo-Si concentrations estimated using both models are in good agreement.
\end{abstract}

(C) 2006 Elsevier B.V. All rights reserved.

Keywords: sponge; germanium; silicon; Ge/Si fractionation; Southern Ocean

* Corresponding author. Tel.: +64 7856 7026; fax: +64 78560151.

E-mail address: m.ellwood@niwa.co.nz (M.J. Ellwood).

\section{Introduction}

The cycling of inorganic germanium $(\mathrm{Ge})$ in the ocean closely matches that of silicon $(\mathrm{Si})[1-3]$. The strong correlation between these two elements, reflected 
in a near constant ratio of $0.7 \mu \mathrm{mol} / \mathrm{mol}\left(r^{2}=0.99\right)$, suggests that the processes that control the distribution of $\mathrm{Si}$ in the ocean also dictate the distribution of $\mathrm{Ge}$ in the ocean $[1,2,4,5]$.

The main group of primary producers that control the cycling of $\mathrm{Si}$ in the ocean are diatoms [6,7]. Although diatoms are only surface dwellers, they control the cycling of Si by stripping it from surface waters to form siliceous tests. The Si within these tests is regenerated at depth when sinking diatom frustules dissolve. Although Ge mimics Si, differences in their geochemical behaviour do occur. The two main sources of Ge and Si to the ocean are from mineral weathering and hydrothermal fluids [8-10]. The main sink for Si removal from the ocean is via incorporation into biogenic opal followed by burial. Like Si, Ge is lost from the ocean via incorporation into biogenic opal followed by burial, however the Ge has addition sink; it is loss via non-opal phases during sediment diagenesis [11-15].

Work by Froelich and co-workers has shown that the $\mathrm{Ge} / \mathrm{Si}$ ratio of small diatoms reflects the seawater $\mathrm{Ge} / \mathrm{Si}$ ratio in which the diatoms grew $[5,16,17]$. This relationship suggests that the $\mathrm{Ge} / \mathrm{Si}$ signature for diatoms could be used to track changes in the cycling of these two elements in the surface ocean. Froelich and coworkers have shown that the $\mathrm{Ge} / \mathrm{Si}$ signature of the ocean has varied in a cyclic manner during the Late Pleistocene. The diatom $\mathrm{Ge} / \mathrm{Si}$ record that they produced shows clear, systematic variations between interglacial $(\mathrm{Ge} / \mathrm{Si}=0.70-0.78 \mu \mathrm{mol} / \mathrm{mol})$ and glacial periods $(\mathrm{Ge} / \mathrm{Si}=0.45-0.60 \mu \mathrm{mol} / \mathrm{mol})$, suggesting that the glacial surface water concentration of Si was higher or that the glacial surface water concentration of Ge was lower $[2,5,11-13,18]$.

While the Ge/Si signature of fossil diatoms has proven to be very useful for tracking changes in the $\mathrm{Ge} / \mathrm{Si}$ ratio of the surface ocean [5], it provides limited insight into the cycling of Ge through the water column. To aid in understanding Ge cycling in the ocean, we present $\mathrm{Ge} / \mathrm{Si}$ results for sponge silica $\left(\mathrm{Ge} / \mathrm{Si}_{\mathrm{sp}}\right)$ collected from a range of depths and locations and present two models to explain the variations found within the data. We then demonstrate that the Ge content of fossil spicules can be used to trace changes in the Si status of the deep ocean.

\section{Materials and methods}

\subsection{Sample acquisition}

Sponges were collected using a rock dredge from the New Zealand research vessels Tangaroa and HMNZS Endeavour, and the Italian vessel Italica.
On collection, specimens were frozen, preserved in $70 \%$ isopropanol, or dried, and subsequently identified to family and ordinal level. All specimens are housed in the NIWA Invertebrate Collection (NIC) at the National Institute of Water and Atmospheric Research, Wellington, NZ. Deep-sea sponge identifications are available upon request.

Filtered $(0.45 \mu \mathrm{m})$ seawater samples were collected using a CTD-rosette system [1] from offshore South Australia $\left(37^{\circ} 07.73^{\prime} \mathrm{S}, 136^{\circ} 54.24^{\prime} \mathrm{E}\right)$ and from the Bounty Trough region (U2795: 46 $\left.38.1^{\prime} \mathrm{S}, 178^{\circ} 30.6^{\prime} \mathrm{E}\right)$. Post collection, samples were stored un-acidified until analysed.

\subsection{Sediment core selection}

The main criterion on sample selection was that they contained sponge spicules. Listed in Table 1 and presented in Fig. 1 are the cores used in the study. Most core samples here were from cores with well defined chronologies. The few top-core samples without an established chronology were assumed to be modern in age (Table 1). The age model established for core Q585 was taken from Weaver et al. [19], which is a modified version of the original model developed by Nelson et al. [20]. The age models established for cores U939 and U938 were taken from Sikes et al. [21].

\subsection{Sample preparation}

Sponge spicules were cleaned by modifying methods previously used for cleaning diatom frustules and sponge spicules $[16,22,23]$. Briefly, dredged sponges were digested at $50{ }^{\circ} \mathrm{C}$ in a hydrochloric acid and hydrogen peroxide (1 M/10\%) solution for five hours. Spicule remains were rinsed with deionised water, digested for one hour in a hot $\left(90{ }^{\circ} \mathrm{C}\right)$ solution of $0.1 \%$ hydroxylamine hydrochloride in $1 \%$ acetic acid, followed by a second hour in a solution of $0.1 \%$ sodium fluoride in $1 \%$ acetic acid. The final cleaning step involved heating in a strong acid solution $\left(50 \% \mathrm{HNO}_{3}: \mathrm{HCl}, 1: 1\right)$ for two hours and then allowing the samples to sit overnight before rinsing four times with deionised water.

Calcium carbonate present in sediment core samples was eliminated by titrating with hydrochloric acid followed by digestion with hydrogen peroxide. Samples were then boiled for $5 \mathrm{~min}$ in a sodium hexametaphosphate $(1 \%)$ solution, diluted, and the process repeated. Sediment samples were sieved at $150 \mu \mathrm{m}$ pore size and 30-50 spicules were selected from the $>150 \mu \mathrm{m}$ fraction under a binocular microscope. Spicules were chemically cleaned as above. 
Table 1

Location and depth information for sponge and sediment cores used in this study

\begin{tabular}{|c|c|c|c|c|}
\hline \multicolumn{2}{|l|}{ Station and sample registration } & \multicolumn{2}{|l|}{ Location } & \multirow[t]{2}{*}{$\begin{array}{l}\text { Depth } \\
\text { (m) }\end{array}$} \\
\hline \multicolumn{4}{|l|}{ Sponge samples } & \\
\hline \multicolumn{5}{|l|}{ Bounty Trough } \\
\hline Z9632 & NIWA 3279 & $43^{\circ} 50.94^{\prime} \mathrm{S}$ & $179^{\circ} 49.75^{\prime} \mathrm{E}$ & 442 \\
\hline $\mathrm{U} 2585$ & NIWA 3280 & $43^{\circ} 49.61^{\prime} \mathrm{S}$ & $178^{\circ} 29.28^{\prime} \mathrm{E}$ & 454 \\
\hline $\mathrm{T} 88$ & NIWA 3281 & $44^{\circ} 02.00^{\prime} \mathrm{S}$ & $174^{\circ} 46.60^{\prime} \mathrm{E}$ & 500 \\
\hline TAN9812/49 & NIWA 3282 & $44^{\circ} 18.74^{\prime} \mathrm{S}$ & $178^{\circ} 13.74^{\prime} \mathrm{E}$ & 663 \\
\hline $\mathrm{U} 2588$ & NIWA 3283 & $44^{\circ} 00.50^{\prime} \mathrm{S}$ & $178^{\circ} 30.00^{\prime} \mathrm{E}$ & 750 \\
\hline TAN9812/84 & NIWA 3284 & $44^{\circ} 32.77^{\prime} \mathrm{S}$ & $178^{\circ} 31.03^{\prime} \mathrm{E}$ & 1073 \\
\hline $\mathrm{U} 2593$ & NIWA 3285 & $44^{\circ} 20.30^{\prime} \mathrm{S}$ & $178^{\circ} 31.67^{\prime} \mathrm{E}$ & 1208 \\
\hline Bollons Seamount & NIWA 2498 & $49^{\circ} 46.1^{\prime} \mathrm{S}$ & $176^{\circ} 45.45^{\prime} \mathrm{W}$ & 1278 \\
\hline Bollons Seamount & NIWA 3025 & $49^{\circ} 46.1^{\prime} \mathrm{S}$ & $176^{\circ} 45.45^{\prime} \mathrm{W}$ & 1278 \\
\hline \multicolumn{5}{|l|}{ North Chatham Rise } \\
\hline $\mathrm{U} 2578$ & NIWA 3286 & $42^{\circ} 48.69^{\prime} \mathrm{S}$ & $178^{\circ} 32.74^{\prime} \mathrm{E}$ & 1000 \\
\hline \multicolumn{5}{|l|}{ Kermadec Seamounts } \\
\hline Kermadec Seamounts & NIWA 2532 & $33^{\circ} 44.18^{\prime} \mathrm{S}$ & $179^{\circ} 49.88^{\prime} \mathrm{E}$ & 619 \\
\hline Kermadec Seamounts & NIWA 2588 & $33^{\circ} 10.25^{\prime} \mathrm{S}$ & $179^{\circ} 58.20^{\prime} \mathrm{W}$ & 999 \\
\hline Kermadec Seamounts & NIWA 2539 & $31^{\circ} 05.03^{\prime} \mathrm{S}$ & $179^{\circ} 01.24^{\prime} \mathrm{W}$ & 1029 \\
\hline Kermadec Seamounts & NIWA 2496 & - & - & 1096 \\
\hline Kermadec Seamounts & NIWA 2535 & $32^{\circ} 35.76^{\prime} \mathrm{S}$ & $179^{\circ} 36^{\prime} \mathrm{W}$ & 1252 \\
\hline Kermadec Seamounts & NIWA 2534 & $32^{\circ} 32.33^{\prime} \mathrm{S}$ & $179^{\circ} 39^{\prime} \mathrm{W}$ & 2312 \\
\hline \multicolumn{5}{|l|}{ Ross Sea, Antarctic } \\
\hline Station 3, Cape Hallett & - & $72^{\circ} 17.51^{\prime} \mathrm{S}$ & $170^{\circ} 26.16^{\prime} \mathrm{E}$ & 300 \\
\hline Station 5, Cape Hallett & - & $72^{\circ} 16.92^{\prime} \mathrm{S}$ & $170^{\circ} 17.09^{\prime} \mathrm{E}$ & 120 \\
\hline A470 & NIWA 3293 & $77^{\circ} 50^{\prime} \mathrm{S}$ & $166^{\circ} 30^{\prime} \mathrm{E}$ & 377 \\
\hline A459 & NIWA 3295 & $75^{\circ} 17^{\prime} \mathrm{S}$ & $172^{\circ} 20^{\prime} \mathrm{E}$ & 542 \\
\hline \multicolumn{5}{|l|}{ Sediment cores } \\
\hline \multicolumn{5}{|l|}{ Bounty Trough } \\
\hline U939 & $1-2 \mathrm{~cm}$ & $44^{\circ} 29.66^{\prime} \mathrm{S}$ & $179^{\circ} 30.08^{\prime} \mathrm{E}$ & 1300 \\
\hline U938 & $6-8 \mathrm{~cm}$ & $45^{\circ} 04.49^{\prime} \mathrm{S}$ & $179^{\circ} 30.38^{\prime} \mathrm{E}$ & 2700 \\
\hline U2603 & $0-1 \mathrm{~cm}$ & $46^{\circ} 38.44^{\prime} \mathrm{S}$ & $178^{\circ} 32.06^{\prime} \mathrm{E}$ & 2764 \\
\hline Q585 & $2.5 \mathrm{~cm}$ & $49^{\circ} 40.10^{\prime} \mathrm{S}$ & $177^{\circ} 59.50^{\prime} \mathrm{W}$ & 4354 \\
\hline \multicolumn{5}{|l|}{ North Pacific } \\
\hline $\mathrm{RC} 12-422$ & $0-1 \mathrm{~cm}$ & $54^{\circ} 24^{\prime} \mathrm{N}$ & $179^{\circ} 37^{\prime} \mathrm{E}$ & 252 \\
\hline VM32-159 & $6-7 \mathrm{~cm}$ & $48^{\circ} 40^{\prime} \mathrm{N}$ & $147^{\circ} 24^{\prime} \mathrm{E}$ & 1235 \\
\hline \multicolumn{5}{|l|}{ North Atlantic } \\
\hline VM23-56 & $0-1 \mathrm{~cm}$ & $62^{\circ} 49^{\prime} \mathrm{N}$ & $25^{\circ} 24^{\prime} \mathrm{W}$ & 617 \\
\hline VM28-70 & $0-1 \mathrm{~cm}$ & $59^{\circ} 05^{\prime} \mathrm{N}$ & $24^{\circ} 41^{\prime} \mathrm{W}$ & 980 \\
\hline VM29-193 & $8-9 \mathrm{~cm}$ & $55^{\circ} 24^{\prime} \mathrm{N}$ & $18^{\circ} 44^{\prime} \mathrm{W}$ & 1326 \\
\hline VM23-42 & $6-7 \mathrm{~cm}$ & $62^{\circ} 11^{\prime} \mathrm{N}$ & $27^{\circ} 56^{\prime} \mathrm{W}$ & 1514 \\
\hline VM29-202 & $2-3 \mathrm{~cm}$ & $60^{\circ} 23^{\prime} \mathrm{N}$ & $20^{\circ} 58^{\prime} \mathrm{W}$ & 2658 \\
\hline VM29-178 & $2-3 \mathrm{~cm}$ & $42^{\circ} 51^{\prime} \mathrm{N}$ & $25^{\circ} 09^{\prime} \mathrm{W}$ & 3448 \\
\hline
\end{tabular}

Sponge spicules were dissolved by adding $1 \mathrm{~mL}$ of $2 \mathrm{M}$ sodium hydroxide (Aristar, BDH) pre-spiked with enriched ${ }^{70} \mathrm{Ge}$ (Chemgas, France). Samples were heated at $85{ }^{\circ} \mathrm{C}$ for $12 \mathrm{~h}$. After cooling, samples were transferred to $5 \mathrm{~mL}$ vials and diluted to $4 \mathrm{~mL}$ with deionised water.

The measured ${ }^{70} \mathrm{Ge} /{ }^{74} \mathrm{Ge}$ ratios varied between 2 and 15 , with the majority of samples having a ${ }^{70} \mathrm{Ge} /{ }^{74} \mathrm{Ge}$ ratio around 8 , our target ratio. A target spike ratio of 8 was chosen to allow an increased dynamic range during sample determination by inductively coupled plasma- mass spectrometry (ICP-MS), and to keep sample counts during pulse detection within range.

\subsection{Silicon and germanium determination}

Silicon concentrations were determined colormetrically [24], while Ge concentrations were determined by isotope dilution using an automated hydride generation system attached to an ICP-MS (Elan-6000, Perkin Elmer, Australia) [3] [25]. The absolute Ge blank associated with the determination of Ge was $0.04 \pm 0.01 \mathrm{pg}$ 


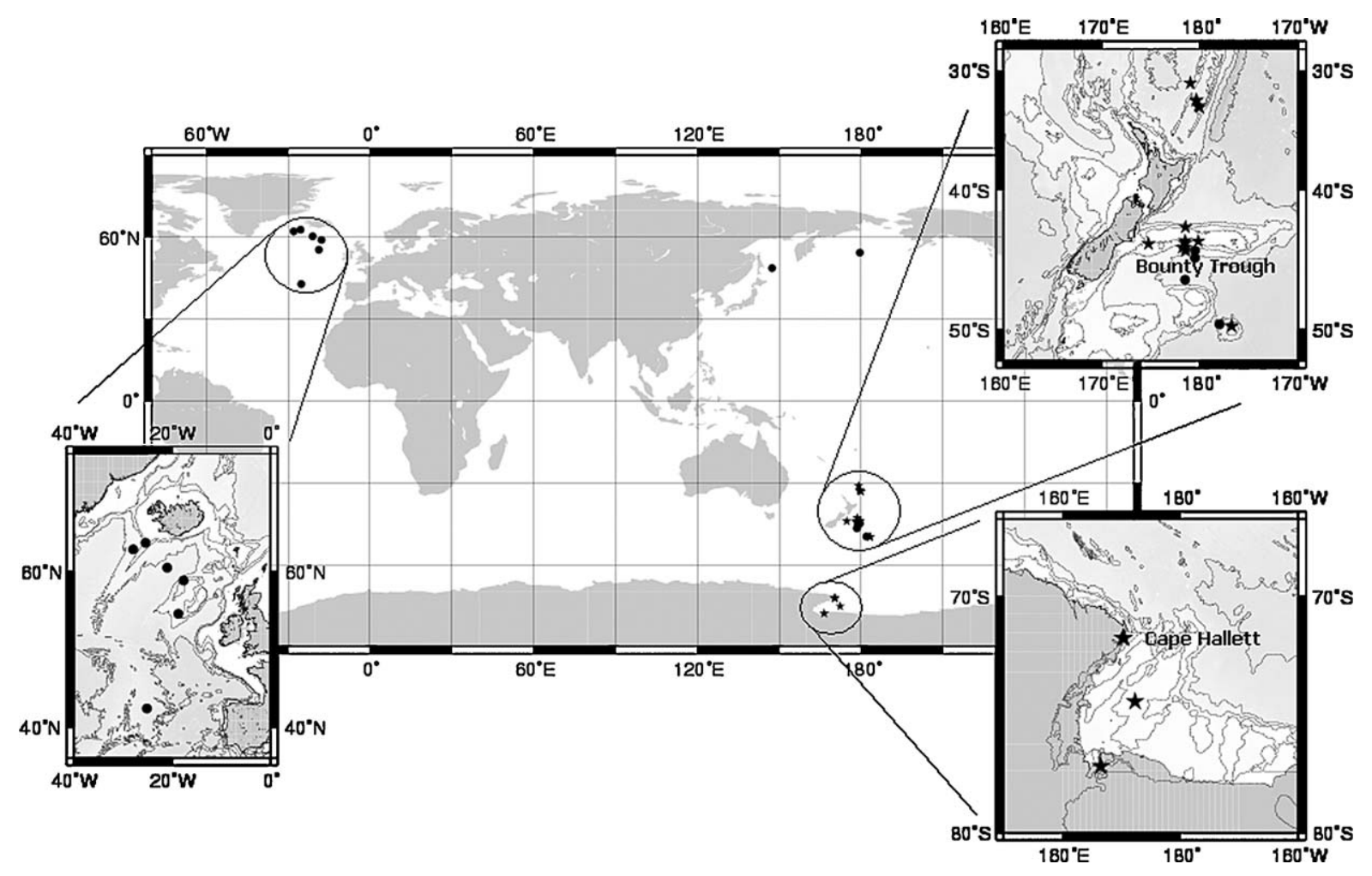

Fig. 1. Location map for dredge sponges (diamonds) and cores (circles) used in this study.

$(n=8)$; which was mainly derived from the sodium borohydride used during the hydride generation process. For sponges collected by dredge, this blank was insignificant. For the majority of sediment spicule samples, the blank represented between $1 \%$ and $8 \%$ of the total $\mathrm{Ge}$ signal. Sponge $\mathrm{Ge} / \mathrm{Si}_{\mathrm{sp}}$ reproducibility was better than $12 \%\left(\mathrm{VM} 28-700-1 \mathrm{~cm}, \mathrm{Ge} / \mathrm{Si}_{\mathrm{sp}}=0.149 \pm\right.$ $0.017 \mu \mathrm{mol} / \mathrm{mol} ;$ mean \pm standard deviation; $n=5$ ). The Ge reproducibility for seawater samples was $\pm 5 \%$ $(n=5)$ at a $\mathrm{Ge}$ concentration of $5.9 \mathrm{pmol} / \mathrm{L}$.

\section{Results and discussion}

\subsection{Sponge Ge/Si versus seawater Ge concentration}

Germanium $/ \mathrm{Si}_{\mathrm{sp}}$ results ranged between about 0.075 to $0.380 \mu \mathrm{mol} / \mathrm{mol}$ (Figs. 2 and 3), which is considerably lower than the seawater $\mathrm{Ge} / \mathrm{Si}$ ratio of $0.7 \mu \mathrm{mol} / \mathrm{mol}$ and indicates that there is significant discrimination of $\mathrm{Ge}$ during $\mathrm{Si}$ uptake and spicule formation. When the $\mathrm{Ge} / \mathrm{Si}_{\mathrm{sp}}$ results were plotted against estimated seawater $\mathrm{Ge}$ concentration for each sponge and core site (Fig. 2), it became apparent that spicule $\mathrm{Ge} / \mathrm{Si}_{\mathrm{sp}}$ increased with increasing seawater $\mathrm{Ge}$ (and $\mathrm{Si}$ ) concentration. This increase was near linear $\left(r^{2}=0.91\right)$ across the range of seawater $\mathrm{Ge}$ and $\mathrm{Si}$ estimated for each site. Plots of $\mathrm{Ge} / \mathrm{Si}_{\mathrm{sp}}$ versus depth for samples collected from different ocean regions showed distinct differences; North Atlantic spicules had lower $\mathrm{Ge} / \mathrm{Si}_{\mathrm{sp}}$ values than Bounty Trough spicules (Fig. 3). Such $\mathrm{Ge} / \mathrm{Si}_{\mathrm{sp}}$ profiles were similar to measured oceanic profiles of dissolved inorganic $\mathrm{Ge}$ for these regions (Fig. 3b). Indeed, the low Ge/ $\mathrm{Si}_{\text {sp }}$ values measured for Atlantic spicules match the low seawater $\mathrm{Ge}$ concentrations measured for this ocean basin. Similarly, the higher $\mathrm{Ge} / \mathrm{Si}_{\mathrm{sp}}$ values measured for Bounty Trough spicules match the higher $\mathrm{Ge}$ concentrations measure sample collected from this oceanic region. There is no readily apparent relationship with that of the seawater $\mathrm{Ge} / \mathrm{Si}$ ratio of $0.7 \mu \mathrm{mol} / \mathrm{mol}$.

The increase of $\mathrm{Ge} / \mathrm{Si}_{\mathrm{sp}}$ with depth is not a temperature or pressure effect on Ge incorporation into sponge silica. This is because sponges collected from a range of sites, with differing pressures and temperatures, all plotted along a single $\mathrm{Ge} / \mathrm{Si}_{\mathrm{sp}}$ versus Ge line. For example, spicules isolated from deep North Atlantic sediments had lower $\mathrm{Ge} / \mathrm{Si}_{\mathrm{sp}}$ values than spicules isolated from deep Bounty Trough sediments, yet deep water temperatures in both regions are within a couple 


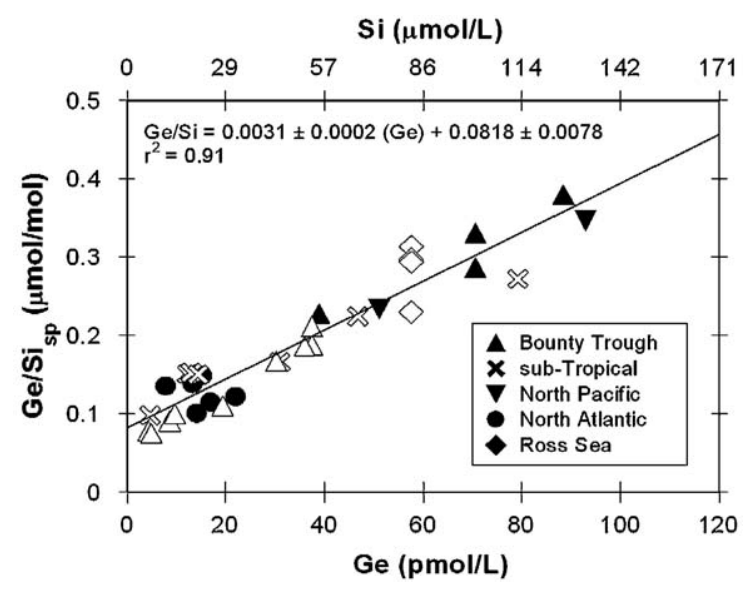

Fig. 2. Germanium content $\left(\mathrm{Ge} / \mathrm{Si}_{\mathrm{sp}}\right)$ of sponge spicules versus $\mathrm{Ge}$ (and $\mathrm{Si}$ ) concentration for dredge sponges and sediment bound spicules. Dissolved Ge concentrations were estimated from existing $\mathrm{Si}$ data (NIWA, GEOSECS and WOCE datasets) for these regions using the modern seawater $\mathrm{Ge} / \mathrm{Si}$ ratio of $0.7 \mu \mathrm{mol} / \mathrm{mol}[2,3]$. As a guide, a scale for $\mathrm{Si}$ concentration, used to estimate Ge concentration, is presented along the top of the graph. The Ge versus Si relationship for the present-day ocean is uniform [2,3], especially for deep water samples, thus the error associated with this Ge estimation is small. Data represent a combination of live-upon-collection dredged material (open symbols) and sediment-bound spicule material (closed symbols).

of degrees of each other. This indicates that temperature does not influence Ge incorporation into sponge silica. Likewise, analysis of two shallow-water specimens collected from off Cape Hallett, Antarctica, where estimated Ge concentrations were around $58 \mathrm{pmol} / \mathrm{L}$, produced relatively high $\mathrm{Ge} / \mathrm{Si}_{\mathrm{sp}}$ values, $0.31 \mu \mathrm{mol} / \mathrm{mol}$ and $0.30 \mathrm{~mol} / \mathrm{mol}$. This result suggests that pressure (depth) does not significantly influence Ge incorporation into sponge silica.

The incorporation of Ge into sponge silica does not appear to be sponge-species dependent. The $\mathrm{Ge} / \mathrm{Si}_{\mathrm{sp}}$ data plotted in Fig. 2 is made up of specimens from a range of hexactinellid and demosponge species, yet all $\mathrm{Ge} / \mathrm{Si}_{\mathrm{sp}}$ ratios increased with increasing seawater $\mathrm{Ge}$ (and $\mathrm{Si}$ ) concentration. In addition, unidentified spicules isolated from cores and sponges collected at adjacent sites produced similar results suggesting that vital effects between species are minimal.

\subsection{Sample homogeneity}

The lower $\mathrm{Ge} / \mathrm{Si}_{\mathrm{sp}}$ ratios found in sponges compared to that of the seawater Ge/Si ratio might suggest that the distribution of Ge within the spicule matrix is uneven. At elevated concentrations (micromolar levels), Ge has be shown to lead to spicule deformation [26-29]. However, the radioisotope work of Davie et al. [30] indicates that only a minimal amount of ${ }^{68} \mathrm{Ge}$ can be found within the central proteinaceous axial filament of spicules. The predominant sink for $\mathrm{Ge}$ within the sponge spicules is the silica matrix that surrounds the filament. The silica proteinaceous axial filament itself is primarily used for initiating and directing spicule formation [28,30-33], thus it may contain minor amounts of Ge resulting from formation of the first few silica laminates [34]. This result indicates that proteinaceous axial filament is not the sink within spicules; rather, it is the silica matrix. Indeed, the amount of carbon within sponge silica is

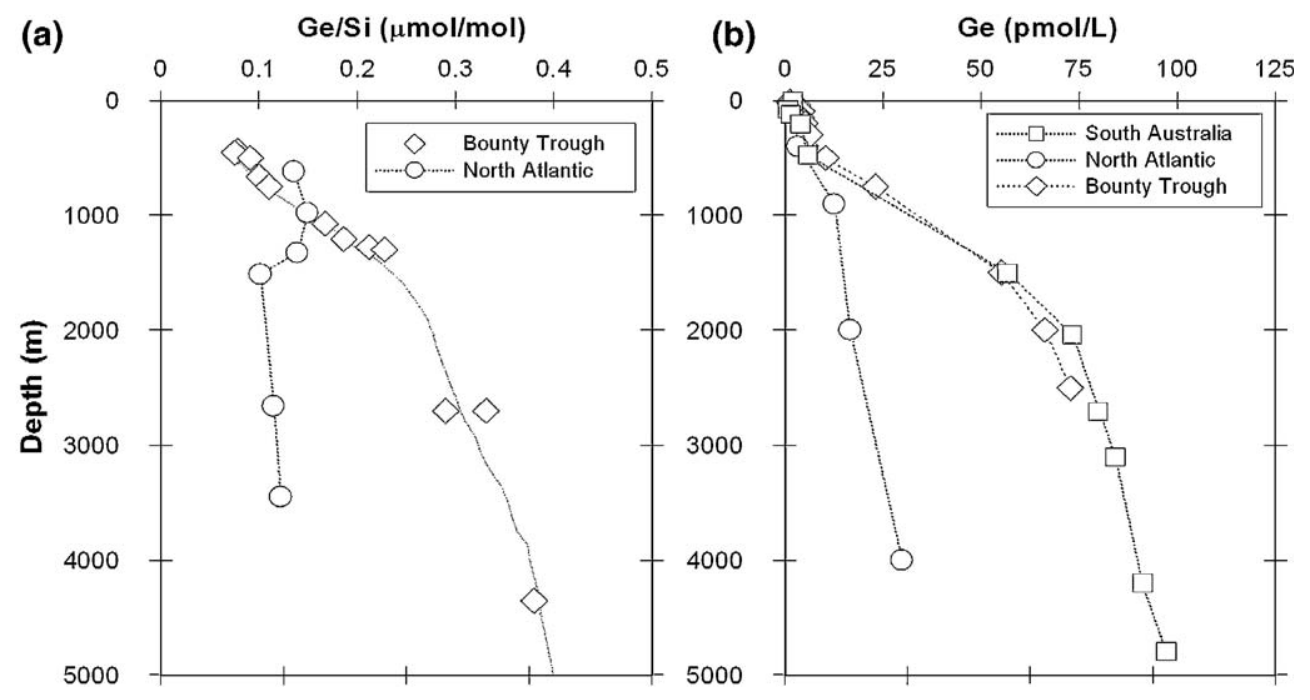

Fig. 3. (a) Depth profiles of $\mathrm{Ge} / \mathrm{Si}_{\text {sp }}$ for sponge spicules from the Bounty Trough and the Northeastern Atlantic. (b) Depth profiles of Ge concentration for the Northwestern Atlantic [3], the Bounty Trough and offshore South Australia. 
low at about $0.05 \%$ by weight [Ellwood, unpublished data, 2005].

\subsection{Mechanism(s) leading to germanium incorporation into sponge silica}

There are two likely mechanisms leading to the increase in the Ge content of sponge silica with increasing $\mathrm{Ge}$ as shown in Fig. 2. 1) The $\mathrm{Ge} / \mathrm{Si}_{\mathrm{sp}}$ of spicules is solely dependent on the Ge concentration of the surrounding seawater and is independent of the $\mathrm{Si}$ concentration of that seawater, and; 2) The $\mathrm{Ge} / \mathrm{Si}_{\mathrm{sp}}$ is a product of strong $\mathrm{Ge} / \mathrm{Si}$ fractionation during $\mathrm{Ge}$ and $\mathrm{Si}$ uptake from the seawater surrounding the sponge.

\subsection{Mechanism I (model I)}

For the first mechanism, if the incorporation of Ge is solely dependent on the Ge concentration, this can be expressed as:

$$
\left(\frac{\mathrm{Ge}}{\mathrm{Si}}\right)_{\mathrm{sp}}=\alpha \cdot[\mathrm{Ge}]_{\text {Seawater }}+c
$$

where the $\mathrm{Ge} / \mathrm{Si}_{\mathrm{sp}}$ equals the seawater $\mathrm{Ge}$ concentration ([Ge $]_{\text {seawater }}$ ) multiplied by a proportionality constant $\alpha$ plus a constant $c$. If this is the case then the $\mathrm{Si}$ in the term $\mathrm{Ge} / \mathrm{Si}_{\text {sp }}$ purely represents the fact that $\mathrm{Ge}$ values have been normalized to silica. In this model we assume that there is no connection between the constant seawater $\mathrm{Ge} / \mathrm{Si}$ ratio of $0.7 \mu \mathrm{mol} / \mathrm{mol}$ and the sponge $\mathrm{Ge} / \mathrm{Si}_{\mathrm{sp}}$ values. Values derived for $\alpha$ and $c$ from fitting the sponge $\mathrm{Ge} / \mathrm{Si}_{\mathrm{sp}}$ to seawater $\mathrm{Ge}$ concentration are $0.0031 \pm 0.0002 \mathrm{~mol}^{-1}$ and $0.082 \pm 0.008 \mu \mathrm{mol} / \mathrm{mol}$, respectively.

There is some evidence to suggest that the incorporation of Ge into sponge silica is solely dependent of the Ge concentration of the surrounding water. This evidence comes from the work of Davie et al. [30] involving the culture of sponge gemmules for the freshwater sponge Spongilla lacustris. In this experiment, gemmules were grown over a range of $\mathrm{Si}$ concentrations but at a fixed ${ }^{68} \mathrm{Ge}$ concentration for two periods, 9 and 11 days. The results from this experiment (Fig. 4a) showed that the amount of ${ }^{68} \mathrm{Ge}$ incorporated into new formed spicules was relatively constant across a Si range of 5 to $150 \mu \mathrm{mol} / \mathrm{L}$. At higher concentrations, the amount of ${ }^{68} \mathrm{Ge}$ declined suggesting either an isotope dilution affect associated with the declining $\mathrm{Ge} / \mathrm{Si}$ ratio of the medium [30], or a decline in the efficiency of $\mathrm{Ge}$ transport into sclerocytes (skeletal secretory cells) [35]. Their results also
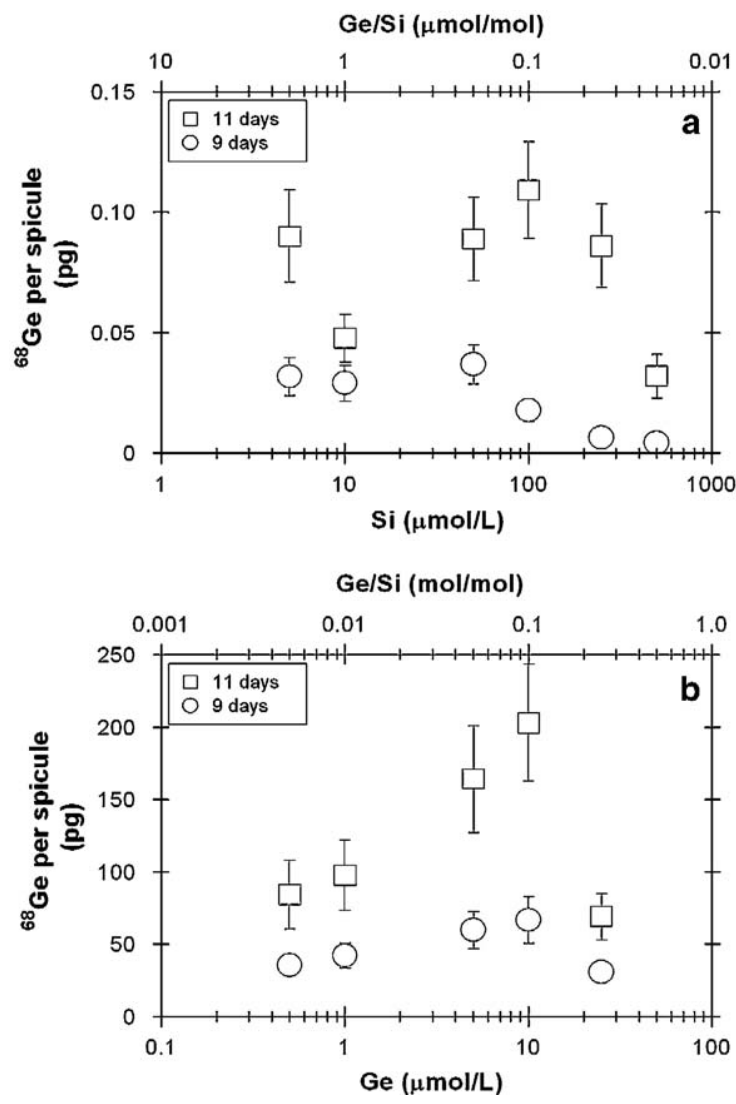

Fig. 4. (a) Incorporation of ${ }^{68} \mathrm{Ge}$ into sponge silica versus increasing $\mathrm{Si}$ concentration. The background Ge concentration was $10 \mathrm{pmol} / \mathrm{L}$. The $\mathrm{Ge} / \mathrm{Si}$ scale presented along the top of this graph, and in panel B, represents the $\mathrm{Ge} / \mathrm{Si}$ ratio of the solution in which gemmules were cultured. Note that the $\mathrm{Ge} / \mathrm{Si}$ of the medium decreases with increasing $\mathrm{Si}$ concentration. (b) The incorporation of ${ }^{68} \mathrm{Ge}$ into sponge silica versus increasing Ge concentration. The background $\mathrm{Si}$ concentration was $100 \mu \mathrm{mol} / \mathrm{L}$. Note that the $\mathrm{Ge} / \mathrm{Si}$ of the medium is increases with increasing Ge concentration. Data used to construct plots were taken from Figs. 1 and 2 of Davie et al. [30].

indicate that the amount of ${ }^{68} \mathrm{Ge}$ is time-dependent; 11 day spicules contained more ${ }^{68} \mathrm{Ge}$ than 9 day spicules (Fig. 4a).

In the reverse experiment, Davie et al. [30] held the Si concentration of the culture medium constant and varied the Ge concentration (Fig. 4b). The results from this experiment showed that the amount of ${ }^{68} \mathrm{Ge}$ incorporated into newly formed spicules increased with increasing Ge concentration. The one issue with relating this experiment to our field data is the concentration of $\mathrm{Ge}$ in the culture medium. Germanium additions to the medium were in the micomolar range, whereas in seawater Ge concentrations are in the low picomolar range (Fig. 4b). However, the 
increase in spicule ${ }^{68} \mathrm{Ge}$ concentration with increasing Ge concentration of the medium is consistent with the $\mathrm{Ge} / \mathrm{Si}_{\mathrm{sp}}$ results we observed for deep-sea sponges (Fig. 2).

Overall, the results from the Davie et al. [30] experiments, the similarity between dissolved Ge and $\mathrm{Ge} / \mathrm{Si}_{\mathrm{sp}}$ profiles (Fig. 3) and the linear relationship established between dissolved $\mathrm{Ge}$ and $\mathrm{Ge} / \mathrm{Si}_{\mathrm{sp}}$ (Fig. 2), all indicate that the Ge concentration of sponge silica can be directly related to the ambient Ge concentration of the waters surrounding sponges and not the actual seawater $\mathrm{Ge} / \mathrm{Si}$ ratio.

\subsection{Mechanism II (model II)}

An alternative scenario to mechanism $\mathrm{I}$ is the possibility that the sponge $\mathrm{Ge} / \mathrm{Si}_{\mathrm{sp}}$ ratio is a product of strong Ge/Si fractionation during Ge and Si uptake from the surrounding seawater. Investigations by Reincke and Barthel [36] and Maldonado et al. [35] indicate that sponges have a much lower affinity for Si than diatoms. Silicon uptake experiments involving the marine sponge Halichondria panicea [36] showed that the uptake of $\mathrm{Si}$ could be modelled using a Michaelis-Menten approach. The results from this study produced a half saturation constant $(\mathrm{Km})$ of $46 \mu \mathrm{mol} / \mathrm{L}$ and a saturation rate $\left(V_{\max }\right)$ of $19 \mu \mathrm{mol} / \mathrm{g} / \mathrm{h}$. The $\mathrm{Km}$ value of $46 \mu \mathrm{mol} / \mathrm{L}$ is considerably larger than the $\mathrm{Km}$ for diatoms, which generally ranges between about 0.2 and $10 \mu \mathrm{mol} / \mathrm{L}$ [37,38]. In contrast, the $V_{\max }$ for $H$. panicea is lower than the $V_{\max }$ for diatoms [37].

We tested the idea that slight differences in the Michaelis-Menten constant, $\mathrm{Km}$, for Ge and Si during uptake led to $\mathrm{Ge} / \mathrm{Si}$ fractionation, by modelling the $\mathrm{Ge} / \mathrm{Si}$ uptake using the following equations:

$V_{\mathrm{Si}}=\frac{V_{\mathrm{Si}_{\max }}[\mathrm{Si}]}{\mathrm{Km}_{\mathrm{Si}}+[\mathrm{Si}]}$

$V_{\mathrm{Ge}}=\frac{V_{\mathrm{Ge}_{\max }}[\mathrm{Ge}]}{\mathrm{Km}_{\mathrm{Ge}}+[\mathrm{Ge}]}$

In this Michaelis-Menten fractionation model, it is assumed that both Ge and $\mathrm{Si}$ are taken up by the one transport system, i.e., Ge behaves as an isotope of $\mathrm{Si}$, therefore what the sponge "sees" is the combined concentrations of $\mathrm{Ge}$ and $\mathrm{Si}$, which is essentially the $\mathrm{Si}$ concentration of the water $\left(\left[\mathrm{Si}^{\prime}\right]\right)$. Assuming that there is no fractionation after uptake, i.e., during silica deposition within the spicule, then the spicule $\mathrm{Ge} / \mathrm{Si}_{\mathrm{sp}}$ ratio should reflect changes in the seawater $\mathrm{Ge} / \mathrm{Si}$ ratio $\left(\mathrm{Ge} / \mathrm{Si} \mathrm{SW}_{\mathrm{SW}}\right)$ and subtle differences in the rate of $\mathrm{Ge}$ and $\mathrm{Si}$ uptake. Along these lines, the $\mathrm{Ge} / \mathrm{Si}_{\mathrm{sp}}$ of sponge silica can be modelled using the following equation:

$$
\left(\frac{\mathrm{Ge}}{\mathrm{Si}}\right)_{\mathrm{sp}}=\frac{V_{\mathrm{Ge}}}{V_{\mathrm{Si}}} \cdot\left(\frac{\mathrm{Ge}}{\mathrm{Si}}\right)_{\mathrm{SW}}=\frac{\frac{V_{\mathrm{Ge}_{\max }}\left[\mathrm{Si}^{\prime}\right]}{\mathrm{Km}_{\mathrm{Ge}}+\left[\mathrm{Si}^{\prime}\right]}}{\frac{V_{\mathrm{Si}_{\max }}\left[\mathrm{Si}^{\prime}\right]}{\mathrm{Km}_{\mathrm{Si}}+\left[\mathrm{Si}^{\prime}\right]}} \cdot\left(\frac{\mathrm{Ge}}{\mathrm{Si}}\right)_{\mathrm{SW}}
$$

Using the Si uptake data from Reincke and Barthel [36] as starting point, where $V_{\text {Simax }}$ and $V_{\text {Gemax }}$ equalled $19 \mu \mathrm{mol} / \mathrm{g} / \mathrm{h}$, and $\mathrm{Km}_{\mathrm{Si}}$ and $\mathrm{Km}_{\mathrm{Ge}}$ equalled $46 \mu \mathrm{mol} / \mathrm{L}$, we modelled the $\mathrm{Ge} / \mathrm{Si}_{\mathrm{sp}}$ data (Fig. 5) by varying $\mathrm{Km}_{\mathrm{Si}}$ and $\mathrm{Km}_{\mathrm{Ge}}$ while holding $V_{\text {Simax }}$ and $V_{\text {Gemax }}$ constant. The $\mathrm{Ge} / \mathrm{Si}_{\mathrm{SW}}$ ratio was set to the present-day value of $0.7 \mu \mathrm{mol} / \mathrm{mol}$. Two assumptions associated are that: a) the maximum uptake rate for $\mathrm{Ge}, V_{\mathrm{Gemax}}$, is the same as it is for $\mathrm{Si}$ and; b) the fractionation seen in the $\mathrm{Ge} / \mathrm{Si}_{\mathrm{sp}}$ data results from differences in $\mathrm{Km}_{\mathrm{Si}}$ and $\mathrm{Km}_{\mathrm{Ge}}$. The assumption that $V_{\text {Simax }}$ and $V_{\text {Gemax }}$ remain the same is required for when $\mathrm{Si}^{\prime}>>\mathrm{Km}_{\mathrm{Si}}$ and $\mathrm{Km}_{\mathrm{Ge}}$ so that $V_{\mathrm{Ge}} / V_{\mathrm{Si}}$ should be equal to one. Using a least squares fitting procedure, we obtained values for $\mathrm{Km}_{\mathrm{Si}}$ and $\mathrm{Km}_{\mathrm{Ge}}$ of 14.2 and $173 \mu \mathrm{mol} / \mathrm{L}$, respectively. In Fig. 5 the model $\mathrm{Ge} / \mathrm{Si}_{\mathrm{sp}}$ curve, along with the original $\mathrm{Ge} / \mathrm{Si}_{\mathrm{sp}}$ data, is plotted versus estimated $\mathrm{Si}^{\prime}$ concentration for each benthic site. As shown, the model curve provides a reasonable fit for the sponge $\mathrm{Ge} / \mathrm{Si}_{\mathrm{sp}}$ data $\left(r^{2}=0.90\right)$. When the $\mathrm{Si}^{\prime}$ is increased to a few thousand $\mu \mathrm{mol} / \mathrm{L}$, the model curve approaches the seawater $\mathrm{Ge} / \mathrm{Si} \mathrm{SW}_{\mathrm{SW}}$ value of $0.7 \mu \mathrm{mol} / \mathrm{mol}$, thereby satisfying our initial assumption that $V_{\text {Simax }}$ equal $V_{\text {Gemax }}$.

The model value of $14.2 \mu \mathrm{mol} / \mathrm{L}$ obtained for $\mathrm{Km}_{\mathrm{Si}}$ is lower than the starting value of $46 \mu \mathrm{mol} / \mathrm{L}$, while the value 173 of $\mu \mathrm{mol} / \mathrm{L}$ obtained for $\mathrm{Km}_{\mathrm{Ge}}$ is considerably

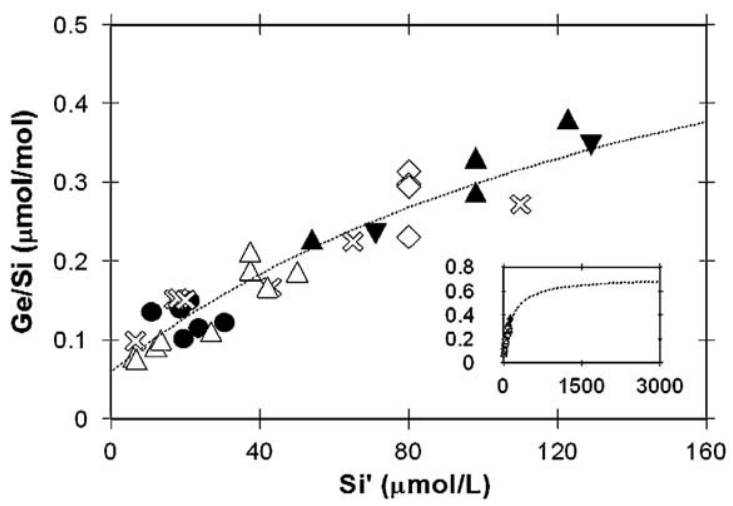

Fig. 5. $\mathrm{Ge} / \mathrm{Si}_{\mathrm{sp}}$ data versus $\mathrm{Si}^{\prime}$ concentration for dredge sponges and sediment bound spicules. Symbols are the same as those in Fig. 2. Dotted line represents the best-fit-line generated using Eq. (4) for model II. Insert plot shows model data covering a $\mathrm{Si}^{\prime}$ concentration from 0 to $3000 \mu \mathrm{mol} / \mathrm{L}$. 
higher than the starting value of $46 \mu \mathrm{mol} / \mathrm{L}$. The large difference between $\mathrm{Km}_{\mathrm{Si}}$ and $\mathrm{Km}_{\mathrm{Ge}}$ results in subtle differences in the rate of uptake of each element and leads to a reduced rate of $\mathrm{Ge}$ uptake relative to Si. Germanium/Si fractionation during uptake is the likely mechanism leading to the low $\mathrm{Ge} / \mathrm{Si}_{\text {sp }}$ ratios observed in sponges compared to that of seawater.

Although differences in Ge and Si uptake kinetics can explain the decline in $\mathrm{Ge} / \mathrm{Si}_{\mathrm{sp}}$ with declining $\mathrm{Si}^{\prime}$ concentration, it cannot explain the sponge culture data from the Davie et al. [30] experiments (Fig. 4), where the incorporation of Ge in sponge silica appears to be independent of $\mathrm{Si}$ at $\mathrm{Si}$ concentrations below about $100 \mu \mathrm{mol} / \mathrm{L}$.

\subsection{Differences between the models}

Although the two models describe the sponge Ge/ $\mathrm{Si}_{\mathrm{sp}}$ reasonable well, the assumptions used to develop each model are different. In the first model, it was assumed that the $\mathrm{Ge} / \mathrm{Si}_{\mathrm{sp}}$ ratio is dependent only on the $\mathrm{Ge}$ concentration of the surrounding seawater. In the second model, subtle differences in the kinetics of $\mathrm{Ge}$ and $\mathrm{Si}$ uptake were used to describe the $\mathrm{Ge} / \mathrm{Si}_{\text {sp }}$ data. Clearly, the exact mechanism(s) leading to $\mathrm{Ge} / \mathrm{Si}$ fractionation will require a detailed culture study to clarify which model best describes Ge incorporation into sponge silica over a range of conditions.

\subsection{The use of the Ge content of sponge spicules for palaeo-chemical reconstructions}

While there are differences between the two models used to describe the sponge $\mathrm{Ge} / \mathrm{Si}_{\mathrm{sp}}$ data, both models can be used to reconstruct changes in ocean Si concentration. Using model I, one can derive Ge concentrations from $\mathrm{Ge} / \mathrm{Si}_{\mathrm{sp}}$ data using Eq. (1) and then coupling this data to the seawater $\mathrm{Ge} / \mathrm{Si}$ ratio to obtain estimates for $\mathrm{Si}$ concentration. Using model II, Eq. (4) can be rearranged to obtain an equation where $\mathrm{Si}^{\prime}$ can be calculated:

$$
\left[\mathrm{Si}^{\prime}\right]=\frac{\left(\frac{\mathrm{Ge}}{\mathrm{Si}}\right)_{\mathrm{SW}} \mathrm{Km}_{\mathrm{Si}}-\left(\frac{\mathrm{Ge}}{\mathrm{Si}}\right)_{\text {opal }} \mathrm{Km}_{\mathrm{Ge}}}{\left(\left(\frac{\mathrm{Ge}}{\mathrm{Si}}\right)_{\text {opal }}-\left(\frac{\mathrm{Ge}}{\mathrm{Si}}\right)_{\mathrm{SW}}\right)}
$$

Like model I, using estimates for seawater $\mathrm{Ge} / \mathrm{Si}$, values for $\mathrm{Si}^{\prime}$ concentration can be obtained from sponge $\mathrm{Ge} / \mathrm{Si}_{\mathrm{sp}}$ data.

As a demonstration, we have determined the $\mathrm{Ge} / \mathrm{Si}_{\mathrm{sp}}$ for fossil spicules isolated from three cores, Q585, U938 and U939, located between $44^{\circ} \mathrm{S}$ and $50^{\circ} \mathrm{S}$, (see Table 1 and Fig. 6). For Q585 and U938, samples cover the last 25-30 kyr, while for U939 samples cover the last 170 kyr.

A general aspect seen in the $\mathrm{Ge} / \mathrm{Si}_{\mathrm{sp}}$ data for Q585 is the decline in values going from 0 to $10 \mathrm{kyr}$ (Fig. 6). For the other deep-water core, U938, a minimum in the Ge/ $\mathrm{Si}_{\text {sp }}$ values occur around 14 kyr. For U939, there is a very slight decline in $\mathrm{Ge} / \mathrm{Si}_{\mathrm{sp}}$ values into marine isotope stage (MIS) 2. Moving from MIS $1 / 2$ transition through to MIS 3, the $\mathrm{Ge} / \mathrm{Si}_{\mathrm{sp}}$ data for Q585 and U938 increase, although there are two spikes in the Q585 record at 14 and $18 \mathrm{kyr}$. The overall reproducibility associated with determining $\mathrm{Ge} / \mathrm{Si}_{\mathrm{sp}}$ ratios is about $12 \%$, thus these peaks are significant. However, we are presently not able to ascribe an oceanic process to these peaks. Further fine-scale sampling of this core, and nearby cores, should help elucidate their origin. For the shallow-water core $\mathrm{U} 939$, the $\mathrm{Ge} / \mathrm{Si}_{\mathrm{sp}}$ data decrease to a minimum around

(a)

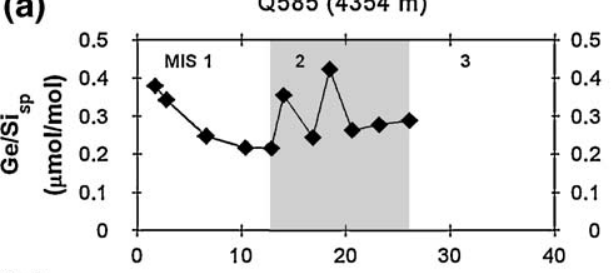

Q585 (4354 m)

U938 $(2700 \mathrm{~m})$

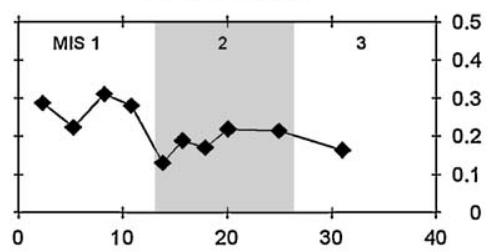

U939 (1300 m)

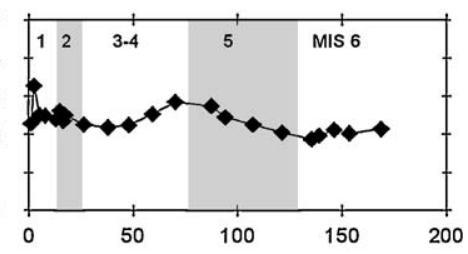

(b)

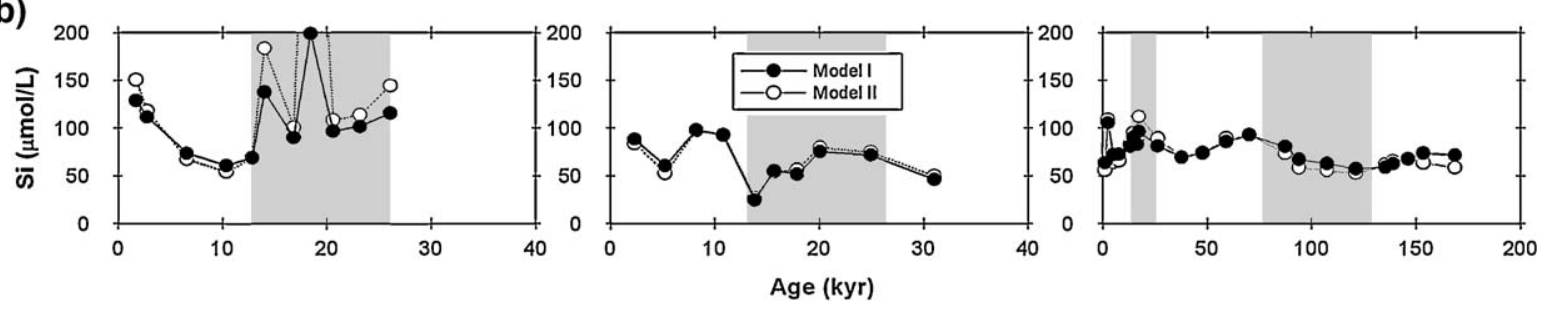

Fig. 6. (a) Ge/ $\mathrm{Si}_{\mathrm{sp}}$ data versus age for spicules isolated from cores Q585, U938 and U939. Note the change in age scale for core U939. (b) Palaeo-Si concentrations estimated using models I and II. 
$40 \mathrm{kyr}$ and gradually increase again to plateau at $70 \mathrm{kyr}$. From 80 kyr onwards, $\mathrm{Ge} / \mathrm{Si}_{\text {sp }}$ values decline again to a second minimum around $135 \mathrm{kyr}$.

Using the $\mathrm{Ge} / \mathrm{Si}_{\text {sp }}$ data for cores Q585, U938 and U939, we have reconstructed palaeo-Si concentrations using both models (Fig. 6). Using model I, we used the relationship described by Eq. (1) to reconstruct palaeoGe concentrations and then divided these values by the seawater $\mathrm{Ge} / \mathrm{Si}$ ratio for that time interval to obtain estimates for $\mathrm{Si}$ (Fig. 6). We used the diatom $\mathrm{Ge} / \mathrm{Si}$ record as a proxy for seawater $\mathrm{Ge} / \mathrm{Si}$ during the past $[5,39]$, and interpolated values to the corresponding spicule sample age. For model II, we used the fitted values for $\mathrm{Km}_{\mathrm{Si}}$ and $\mathrm{Km}_{\mathrm{Ge}}$ and combined them with the diatom $\mathrm{Ge} / \mathrm{Si}$ record for past seawater $\mathrm{Ge} / \mathrm{Si}$ to compute values for $\mathrm{Si}^{\prime}$ using Eq. (5) (Fig. 6). As can be seen, generally there is good agreement between both models for estimating palaeo-Si. The only significant deviation between the two models is for the two spikes seen in the $\mathrm{Ge} / \mathrm{Si}_{\mathrm{sp}}$ record for core $\mathrm{Q} 585$. The high $\mathrm{Si}^{\prime}$ values produced by model II result from spike $\mathrm{Ge} / \mathrm{Si}_{\mathrm{sp}}$ values being in a region where the model starts to flatten out; in this region, a small variation in $\mathrm{Ge} / \mathrm{Si}_{\text {sp }}$ leads to large variation in the estimation of $\mathrm{Si}^{\prime}$ concentration. Overall, model agreement suggests that, while the exact mechanism(s) leading to $\mathrm{Ge} / \mathrm{Si}$ fractionation in sponges is not well understood, the $\mathrm{Ge} / \mathrm{Si}_{\mathrm{sp}}$ ratio of sponge spicules can be used to reconstruct palaeo-Si concentrations.

The reconstruction of palaeo-Si concentration is particularly valuable because there is conflicting evidence on the nutrient status of the deep Southern Ocean during glacial times [40-43]. Interpretation of $\delta^{13} \mathrm{C}$ data from benthic foraminifera suggests that the deep Southern Ocean was nutrient-enriched during glacial times $[41,40]$, while trace metal proxies for nutrients suggest that the nutrient content of the glacial Southern Ocean was similar to present-day levels $[42,43]$. Detailed sponge $\mathrm{Ge} / \mathrm{Si}_{\mathrm{sp}}$ records from the Southern Ocean should help clarify its nutrient status during the past, and help elucidate the processes leading to disagreement between nutrient proxies.

\section{Conclusions}

Germanium/Si ratios for sponge spicules collected by dredge and isolated from sediments ranged between 0.075 and $0.380 \mu \mathrm{mol} / \mathrm{mol}$. Such values are lower than the present-day seawater $\mathrm{Ge} / \mathrm{Si}$ ratio of $\sim 0.7 \mu \mathrm{mol} / \mathrm{mol}$. A plot of $\mathrm{Ge} / \mathrm{Si}_{\mathrm{sp}}$ versus estimated seawater $\mathrm{Ge}$ (and $\mathrm{Si}$ ) concentration produced a linear relationship. A plot of $\mathrm{Ge} / \mathrm{Si}_{\mathrm{sp}}$ versus depth for sponge spicules collected from sponges and isolated from sediments produced oceanic profiles similar to those of dissolved Ge and Si concentration, thereby indicating that the incorporation of $\mathrm{Ge}$ into spicules is not simply associated to the seawater $\mathrm{Ge}$ / $\mathrm{Si}$ ratio. The mechanism(s) leading to such $\mathrm{Ge} / \mathrm{Si}_{\mathrm{sp}}$ fractionation have been modelled using two approaches. The first modelling approach assumes that the sponge $\mathrm{Ge} / \mathrm{Si}_{\mathrm{sp}}$ ratio is a direct result of the prevailing $\mathrm{Ge}$ concentration of seawater. The Ge/ Si ratio of seawater is not assumed to influence Ge incorporation.

The second model assumes that the sponge $\mathrm{Ge} / \mathrm{Si}_{\mathrm{sp}}$ ratio results from subtle differences in the uptake kinetics of $\mathrm{Ge}$ and $\mathrm{Si}$ into sponges. Using both models, good fits of the $\mathrm{Ge} / \mathrm{Si}_{\mathrm{sp}}$ data were obtained. Using either model, reconstruction of palaeo-Si concentrations is possible using the Ge signature of fossil spicules isolated from sediment cores. Palaeo-Si estimates using both models produce similar results, and highlight the possibility of using this proxy to reconstruct the nutrient status of the deep ocean.

\section{Acknowledgements}

We sincerely thank Philip Froelich for providing the $\mathrm{Ge} / \mathrm{Si}$ diatom record, Simon Thrush and colleagues for collecting the Cape Hallett sponges, Frank Krikowa for help with sample analyses, Stu Pickmere for silica profiles, Lionel Carter for comments on an earlier version of the manuscript and two anonymous reviewers and Harry Elderfield for comments that helped to improve the manuscript. We also thank the Lamont Doherty Earth Observatory (LDEO) for providing sediment core material. Financial support for the study was provided by a Royal Society of New Zealand Marsden Fund grant to M.E. Sponge and core collection and curation is supported by the New Zealand Foundation for Research Science and Technology (NIWA), the New Zealand Ministry of Fisheries (NIWA), the University of Canberra (EcoChemistry Laboratory), the Australian Research Council (ANU, awarded to PDD.), the National Science Foundation (LDEO) and the Office of Naval Research (LDEO).

\section{References}

[1] P.N. Froelich, M.O. Andreae, The marine geochemistry of germanium-Ekasilicon, Science 213 (1981) 205-207.

[2] P.N. Froelich, R.A. Mortlock, A. Shemesh, Inorganic germanium and silica in the Indian Ocean: biological fractionation during $(\mathrm{Ge} /$ Si)opal formation, Glob. Biogeochem. Cycles 3 (1989) 79-88.

[3] R.A. Mortlock, P.N. Froelich, Determination of germanium by isotope dilution hydride generation inductively coupled plasma mass spectrometry, Anal. Chim. Acta 332 (1996) 277-284.

[4] P.N. Froelich, G.A. Hambrick, M.O. Andreae, R.A. Mortlock, J.M. Edmond, The geochemistry of inorganic germanium in natural waters, J. Geophys. Res. 90 (1985) 1133-1141. 
[5] P.N. Froelich, V.R. Vlanc, R.A. Mortlock, S.N. Chillaud, W. Dustan, A. Udomkit, T.H. Peng, River fluxes of dissolved silica to the ocean were higher during glacials: $\mathrm{Ge} / \mathrm{Si}$ in diatoms, rivers and oceans, Paleoceanography 7 (1992) 739-767.

[6] P. Treguer, D.M. Nelson, A.J. Vanbennekom, D.J. Demaster, A. Leynaert, B. Queguiner, The silica balance in the world ocean - a reestimate, Science 268 (1995) 375-379.

[7] D.M. Nelson, P. Treguer, Role of silicon as a limiting nutrient to Antarctic diatoms - evidence from kinetic-studies in the Ross Sea Ice-Edge Zone, Mar. Ecol. Prog. Ser. 80 (1992) $255-264$.

[8] A.C. Kurtz, L.A. Derry, O.A. Chadwick, Germanium-silicon fractionation in the weathering environment, Geochim. Cosmochim. Acta 66 (2002) 1525-1537.

[9] R.A. Mortlock, P.N. Froelich, Continental weathering of germanium- $\mathrm{Ge} / \mathrm{Si}$ in the global river discharge, Geochim. Cosmochim. Acta 51 (1987) 2075-2082.

[10] R.A. Mortlock, P.N. Froelich, R.A. Feely, G.J. Massoth, D.A. Butterfield, J.E. Lupton, Silica and germanium in Pacific Ocean hydrothermal vents and plumes, Earth Planet. Sci. Lett. 119 (1993) 365-378.

[11] J. McManus, D.E. Hammond, K. Cummins, G.P. Klinkhammer, W.M. Berelson, Diagenetic Ge-Si fractionation in continental margin environments: further evidence for a nonopal Ge sink, Geochim. Cosmochim. Acta 67 (2003) 4545-4557.

[12] D.E. Hammond, J. McManus, W.M. Berelson, C. Meredith, G.P. Klinkhammer, K.H. Coale, Diagenetic fractionation of Ge and $\mathrm{Si}$ in reducing sediments: the missing $\mathrm{Ge}$ sink and a possible mechanism to cause glacial/interglacial variations in oceanic Ge/Si, Geochim. Cosmochim. Acta 64 (2000) 2453-2465.

[13] S.L. King, P.N. Froelich, R.A. Jahnke, Early diagenesis of germanium in sediments of the Antarctic South Atlantic: in search of the missing Ge sink, Geochim. Cosmochim. Acta 64 (2000) 1375-1390.

[14] R.J. Murnane, B. Leslie, D.E. Hammond, R.F. Stallard, Germanium geochemistry in the Southern California borderlands, Geochim. Cosmochim. Acta 53 (1989) 2873-2882.

[15] D.E. Hammond, J. McManus, W.M. Berelson, Oceanic germanium/silicon ratios: evaluation of the potential overprint of temperature on weathering signals, Paleoceanography 19 (2004), doi:10.1029/2003PA000940.

[16] A. Shemesh, R.A. Mortlock, R.J. Smith, P.N. Froelich, Determination of $\mathrm{Ge} / \mathrm{Si}$ in marine siliceous microfossils - separation, cleaning and dissolution of diatoms and radiolaria, Mar. Chem. 25 (1988) 305-323.

[17] A. Shemesh, R.A. Mortlock, P.N. Froelich, Late Cenozoic Ge/Si record of marine biogenic opal: implications for variations of riverine fluxes to the ocean, Paleoceanography 3 (1989) 221-234.

[18] R.A. Mortlock, C.D. Charles, P.N. Froelich, M.A. Zibello, J. Saltzman, J.D. Hays, L.H. Burckle, Evidence for lower productivity in the Antarctic Ocean during the last glaciation, Nature 351 (1991) 220-223.

[19] P.P.E. Weaver, L. Carter, H.L. Neil, Response of surface water masses and circulation to Late Quaternary climate change east of New Zealand, Paleoceanography 13 (1998) 70-83.

[20] C.S. Nelson, C.H. Hendy, A.M. Cuthbertson, Compendium of Stable Oxygen and Carbon Isotope Data for the Late Quaternary Interval of Deep-Sea Cores from the New Zealand Sector of the Tasman Sea and Southwest Pacific Ocean, University of Waikato, Hamilton, 1993.

[21] E.L. Sikes, W.R. Howard, H.L. Neil, J.K. Volkman, Glacialinterglaical sea surface temperature changes across the subtrop- ical front east of New Zealand based on alkenone unsaturation ratios and foraminiferal assemblages, Paleoceanography 17 (2002)

[22] M.J. Ellwood, M. Kelly, S.D. Nodder, L. Carter, Zinc/silicon ratios of sponges: a proxy for carbon export to the seafloor, Geophys. Res. Lett. 31 (2004), doi:10.1029/2004GL019648.

[23] M.J. Ellwood, M. Kelly, H. Neil, S.D. Nodder, Reconstruction of paleo-particulate organic carbon fluxes for the Campbell Plateau region of southern New Zealand using the zinc content of sponge spicules, Paleoceanography 20 (2005), doi:10.1029/ 2004PA001095.

[24] I. Koroleff, Analysis of micronutrients, in: K. Grasshof (Ed.), Methods of Seawater Analysis, Verlag-chimie, Berlin, 1976, pp. 134-145.

[25] M.J. Ellwood, W.A. Maher, An automated hydride generationcryogenic trapping-ICP-MS system for measuring inorganic and methylated $\mathrm{Ge}, \mathrm{Sb}$ and As species in marine and fresh waters, J. Anal. At. Spectrom. 17 (2002) 197-203.

[26] T.L. Simpson, L.M. Refolo, M.E. Kaby, Effects of germanium on the morphology of silica deposition in a freshwater sponge, J. Morphol. 159 (1979) 343-354.

[27] T.L. Simpson, P.F. Langenbruch, Effects of morphogenesis of a complex silica structure and on the assembly of the collagenous gemmule coat in a freshwater sponge, Biol. Cell 50 (1984) 181-190.

[28] T.L. Simpson, M. Gil, R. Connes, J.P. Diaz, J. Paris, Effects of germanium $(\mathrm{Ge})$ on the silica spicules of the marine sponge Suberites domuncula: transformation of spicule type, J. Morphol 183 (1985) 117-128.

[29] T.L. Simpson, R. Garrone, M. Mazzorana, Interaction of germanium (Ge) with biosilicification in the freshwater sponge Ephydatia mülleri: evidence of localized membrane domains in the silicalemma, J. Ultrastruct. Res. 85 (1983) 159-174.

[30] E.I. Davie, T.L. Simpson, R. Garonne, Experimental germanium incorporation into siliceous sponge spicules, Biol. Cell 48 (1983) 191-202.

[31] J.N. Cha, G.D. Stucky, D.E. Morse, T.J. Deming, Biomimetic synthesis of ordered silica structures mediated by block copolypeptides, Nature 403 (2000) 289-292.

[32] K. Shimizu, J. Cha, G.D. Stucky, D.E. Morse, Silicatein alpha: cathepsin L-like protein in sponge biosilica, Proc. Natl. Acad. Sci. U. S. A. 95 (1998) 6234-6238.

[33] J.N. Cha, K. Shimizu, Y. Zhou, S. C. Christiansen, B.F. Chmelka, G.D. Stucky, D.E. Morse, Silicate in filaments and subunits from a marine sponge direct the polymerization of silica and silicones in vitro, Proc. Natl. Acad. Sci. U. S. A. 96 (1999) 361-365.

[34] F. Sanford, Physical and chemical analysis of the siliceous skeletons in six sponges of two groups (Demospongiae and Hexactinellida), Microsc. Res. Tech. 62 (2003) 336-355.

[35] M. Maldonado, M.G. Carmona, M.J. Uriz, A. Cruzado, Decline in Mesozoic reef-building sponges explained by silicon limitation, Nature 401 (1999) 785-788.

[36] T. Reincke, D. Barthel, Silica uptake kinetics of Halichondria panicea in Kiel Bight, Mar. Biol. 129 (1997) 591-593.

[37] V. Martin-Jezequel, M. Hildebrand, M.A. Brzezinski, Silicon metabolism in diatoms: implications for growth, J. Phycol. 36 (2000) 821-840.

[38] E. Paasche, Silicon and the ecology of marine plankton diatoms. II. Silicate-uptake kinetics in five diatom species, Mar. Biol. 19 (1973) 262-269. 
[39] G. Bareille, M. Labracherie, R.A. Mortlock, E. Maier-Reimer, P.N. Froelich, A test of $(\mathrm{Ge} / \mathrm{Si})_{\text {opal }}$ as a paleorecorder of $(\mathrm{Ge} / \mathrm{Si})_{\text {seawater, }}$ Geology 26 (1998) 179-182.

[40] I.R. Hall, I.N. McCave, N.J. Shackleton, G.P. Weedon, S.E. Harris, Intensified deep Pacific inflow and ventilation in Pleistocene glacial times, Nature 412 (2001) 809-812.

[41] C.S. Nelson, P.J. Cooke, C.H. Hendy, A.M. Cuthbertson, Oceanographic and climatic changes over the past 160,000 years at deep-sea drilling project site-594 off Southeastern New-
Zealand, Southwest Pacific-Ocean, Paleoceanography 8 (1993) 435-458.

[42] E.A. Boyle, Cadmium and delta-C13 paleochemical ocean distributions during the stage 2 glacial maximum, Annu. Rev. Earth Planet. Sci. 20 (1992) 245-287.

[43] D.W. Lea, A trace metal perspective on the evolution of Antarctic circumpolar deep water chemistry, Paleoceanography 10 (1995) 733-747. 